\title{
Social-economic aspects of development of Lviv Region in conditions of modern processes of Eurointegration
}

\author{
Natalia Tomczewska-Popowycz \\ Department of Regional Geography and Tourism, Faculty of Earth Sciences, University of Silesia Będzińska Str. 60, 41-200 Sosnowiec, \\ Poland \\ E-mail address: nata_pop@ukr.net
}

\begin{abstract}
Eurointegration is an important direction for Ukraine, especially in present political situation. Social-economic condition is very important for entering into European organizations. In this article social-economic aspects of Lviv Region, which is a border region, in conditions of modern Eurointegration are studied. On the basis of the statistic report of social-economic condition of Lviv Region of Main Department of Statistics in Lviv Region an analysis was done, which allowed making conclusions of actual condition of the region. The task of the study is to determine basic directions of regional socialeconomic development. Main methodological approaches are systemic, chorological and chronological and also such approaches as synergetic and informational. Demographic situation of the region is being analyzed in the article, in particular indicators of natural and mechanic movement of the population, and gender-age structure of the population is also described. Peculiarities of economic development of the region are revealed, indicators of gross regional product and index of competitiveness are analyzed. The condition and tendencies of research and innovation activity of the region are presented, and also a situation in small and medium business is depicted. The studies have demonstrated, that Lviv Region, in comparison with other regions of Ukraine, is characterized by high enough social-economic development. Non-productive branch, the part of which is a scientific potential (research and project-design establishments, higher educational institutions), financial organizations, trade enterprises and food industry, which totally can satisfy the needs of the region, are relatively well developed. At the same time there are also unfavorable demographic tendencies in the region, in particular depopulation of the population is the result of negative natural growth. Perspectives of the development of the region are proposed in the article, in particular the direction of regional strategy and cross-border cooperation.
\end{abstract}

KEY WORDS: Lviv Region, border region, demographic situation, scientific activity, innovation activity

\section{Introduction}

The peculiarity of the modern international processes is globalization and regionalization as the bases of economic development. These processes have positive impact on the development of world community, but they are also accompanied by sudden appearance of dangerous phenomena and processes in the form of world financialeconomic crisis, international terrorism, aggravation of man-made and natural disasters etc. Globalization and Eurointegration lead to increasing intensiveness of mutual relations in the sphere of trade, finances, migration of population as a result of development of all-embracing systems of transport and communications.
An important feature of the border regions is their remoteness from the centre of the country and closeness to the neighboring countries, which positively influences the development of the ethno-cultural relations, foreign trade activity and investing activity. These aspects gain special meaning in conditions of Eurointegration processes in Ukraine.

Under formed circumstances every country of the world built its own model of the further development, trying to most successfully use its natural-geographic, geopolitical peculiarities and advantages, justifying centers and vectors of its influence, determining most useful partners for further cooperation. Thereby, more value meaning gains the question of research of border regions, 
which, from one hand, are characterized by peripheral position and from the other hand have certain additional advantages, the usage of which will allow improving their social-economic condition, decreasing the disproportion in territorial development.

The notion of the standard of living of population embraces the satisfaction from physical, psychological and social needs of the population, and also conditions of development of the society, including incomes, consumption, employment, working conditions, health condition of the population, lifetime, education, cultural development, social rights and other. The notion of the life quality in turn depicts the general prosperity of the society and combines such categories, as satisfaction from life, freedom of choice, safety, environmental conditions. Standard of living of population depends on macroeconomic factors and way of life. In this context the subject of the analysis is an impact of economic, social, cultural, innovation, ecologic and other conditions on the standard of living of population.

European integration is a top priority of external policy of Ukraine. On the modern stage the content of the Eurointegration changes in internal political and international contexts. For Ukrainian society the European integration gains a new meaning, transforming from external political course into complex domestic policy (ZOLKINA, 2014).

In research of territorial aspects of economic and social development were engaged such scientists as BUTKO (2005), KоROTYCH $(2006,2007$, 2008), Cherevko (2007), Nemets ET AL., (2014), and others. But theoretical approaches to the complex estimation of internal potential of certain regions have lack of attention.

\section{Purpose and methods of the article}

In conditions of modern processes of Eurointegration the realization of national interests with the help of effective regional policy is an important task. It should also be noted, that Eurointegration plays an important role in forming of postindustrial society, supports the providing of guarantees of quality of life of the population. Lviv Region is one of the border regions of Ukraine. Social-economic development of border regions is largely determined by peculiarities of determination of ways of optimization of cooperation of society and natural environment. In this regard the need of complex social-geographic studying of border regions with the purpose of revealing of peculiarities and tendencies of their development under circumstances of modern Eurointegration of Ukraine arises.

Actual social-politic situation in Ukraine and in Lviv Region, recent revolutionary events radically changed personnel of authorities, which has influenced also the economic situation of the country and Lviv Region. On the basis of the statistic report of social-economic condition of Lviv Region of Main Department of Statistics in Lviv Region it was done the analysis, which allows to make a conclusion of actual situation of the region, to analyze the power of impact of politic factor and to form forecasts of development of Lviv Region.

Key task of social-geographic studies is to determine ways of optimization of cooperation of the society and natural environment, to reveal basic directions of regional social-economic development. That is why the main methodological approaches are systemic, chorological and chronological and also new ones for geography approaches, such as synergetic and informational. These approaches allow studying social-economic and natural systems in their variety and cooperation and are used in research of border regions.

\section{Lviv Region}

Lviv Region is situated in central-eastern Europe, in the west of Ukraine. It is the part of Carpathian Euroregion. It has the common border with the Republic of Poland. The territory of the region consists of plain, foothill and mountain (the Ukrainian Carpathians) parts. The forests take the fourth part of the area of the region. The territory of the region has the international communications, which connect Ukraine with Poland, Romania, Slovakia and Hungary. The northern part of the region lies within the Volyn Upland and the Podillia Upland, separated by the valley of the Dniester River from the Precarpathians. In the southern west of the region the chains of the Ukrainian Carpathians are situated (ZASTAVNIJ, 1994).

Border Lviv Region has one of the highest indicators of standard of living in Ukraine. Accordingly the index of social development it takes the fourth place after Kharkiv, Zakarpattia and Chernivtsi Regions. Lviv Region is characterized by favorable ecologic and medical-demographic situation in comparison with other regions of Ukraine (ANALIZ SANITARNO-EPIDEMIOLOGICHNOI SITUACIÏ..., 2011; DovKILLIA LVIVSHINI, 2013; RIVEN' ZhitTya NASELENNya UKRAÏNI, 2006; PANTYleJ, 2008). 


\section{Results of studies}

Lviv Region takes the $5^{\text {th }}$ place in Ukraine by the number of population after Donetsk, Dnipropetrovsk, Kyiv and Kharkiv Regions, and also $17^{\text {th }}$ place by the area. Modern economics of Lviv Region is quite powerful economic complex, which by its productive, scientific-technical and working capacity can be considered as one of the largest in Ukraine. The high level of the development of economics of the region is conditioned by favorable economic-geographic position, quite rich naturalresource potential, historic-political peculiarities of the development and demographic capital.

\subsection{Population}

As of May 1, 2015 in Lviv Region 2534232 persons lived, which is $6 \%$ of number of the whole population of Ukraine (MAIN DEPARTMENT of Statistics in LViv Region, 2015). The region takes the second place in Ukraine by index of population density, just after Donetsk Region. The average population density is 116.4 pers. $/ \mathrm{km}^{2}$, while in Ukraine this index is 75.3. It also should be noted, that for Ukraine in general and for Lviv Region it is characteristic the significant depopulation of the population (Fig. 1).

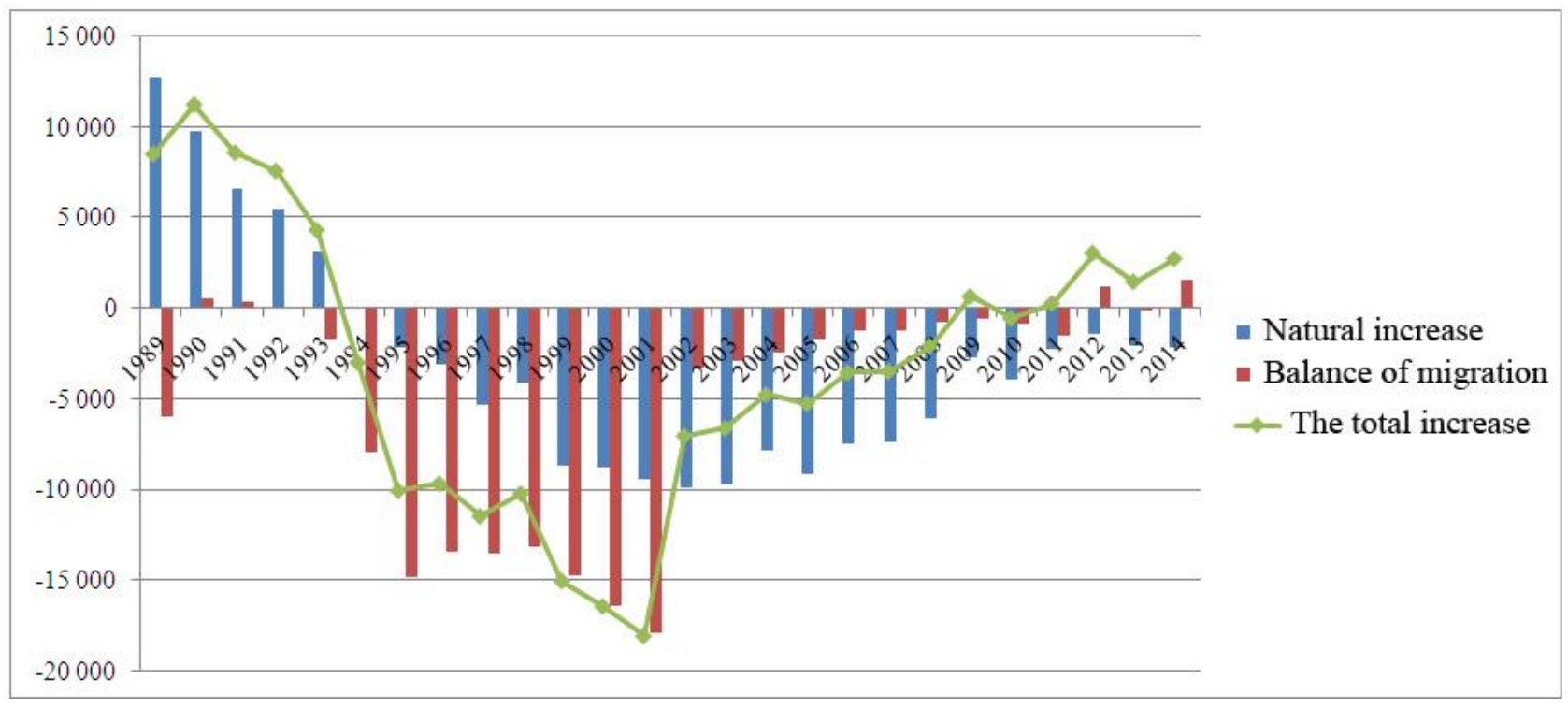

Fig. 1. Dynamics of natural and migration movement of the population in Lviv Region for the period of 1989-2014. It is processed on the basis of the data from Main Department of Statistics of Lviv Region

In 2013 compared with 2014 the index of natural decreasing calculated to existing population did not changed, but in comparison with 2012 it decreased. Birth rate in villages is higher than in cities. Basic tendencies in natural movement of the population are limited to following indicators: fertility as a result of influence of a range of politic-economic and social-psychological factors was decreasing till the year of 2000 , after that gradual increasing is observed and stabilization in 2009-2014. Positive changes in the process of birth rate can be explained by the action of internal and external factors. The most important internal factor of the birth rate is the change of old-age fertility intensity. The essential meaning of this factor can be explained by corresponding changes in industrially developed regions, which Lviv Region also concerns. Increasing of fertility is also observed as a result of delay of baby birth and phenomenon of late maternity. Among external factors of fertility increasing it must be mentioned the relative stabilization of social-economic situation in the country, providing of increased financial assistance at childbirth in Ukraine etc. And there are also changes in the process of self family: transfer from two children to one child model of reproductive behavior, which corresponds to modern European tendencies.

The level of mortality of Lviv Region has been more or less stable during 1995-2014 (12-13\%o), which is the expressing of the gender-age structure of the population (OFFICIAL WEBSITE OF MAIN DEPARTMENT OF STATISTICS, 2015). It can be suggested, that the level of mortality of the population will further be at the same level: the present working-age population will pass into older age groups.

Considering its border situation and level of social-economic development Lviv Region is migrationally attractive. Since 2012 it has been fixed the increasing of the population exactly due to high positive balance of migration, which is 
presented in shortening of rates of depopulation of the population. It can be explained by unstable situation in the east of the country and numerous emigrations from the dangerous regions.

The gender-age structure of the population of Lviv Region is characterized by increasing of number of the youth due to increasing of the fertility, significant working capacity and even correlation of genders of reproductive age. Specific weight of children of gender-age structure of the population of the region $(0-15$ years $)$ is $15.8 \%$, and the population of older age groups (60 years and over) is $14.4 \%$. In the structure of the population prevails the population of the working age (its specific weight in general number is $69.8 \%$ ). In average, in 2014 per one inhabitant it was accounted for 22.8 sq. $\mathrm{m}$ of general living space, this indicator is similar to the average one in the country.

\subsection{Industry}

In the structure of industrial production of the region the most meaning have food, fuel industries, engineering, metalworking and electricity. Lviv Region takes $15^{\text {th }}$ place in Ukraine by production of plant products and $3^{\text {rd }}$ by production of livestock products. By part of farm properties of the population in general extent of the gross products of agriculture in farm properties of the population the region takes the first place among other regions of Ukraine.

At Fig. 2 it is presented the dynamics of indexes of industrial production in Lviv Region, the analysis of which allows noting of financial and economic crisis in the region in 2009, and since 2012 it is observed the decreasing of the scope of production, which negatively influenced the social-economic development of the region.

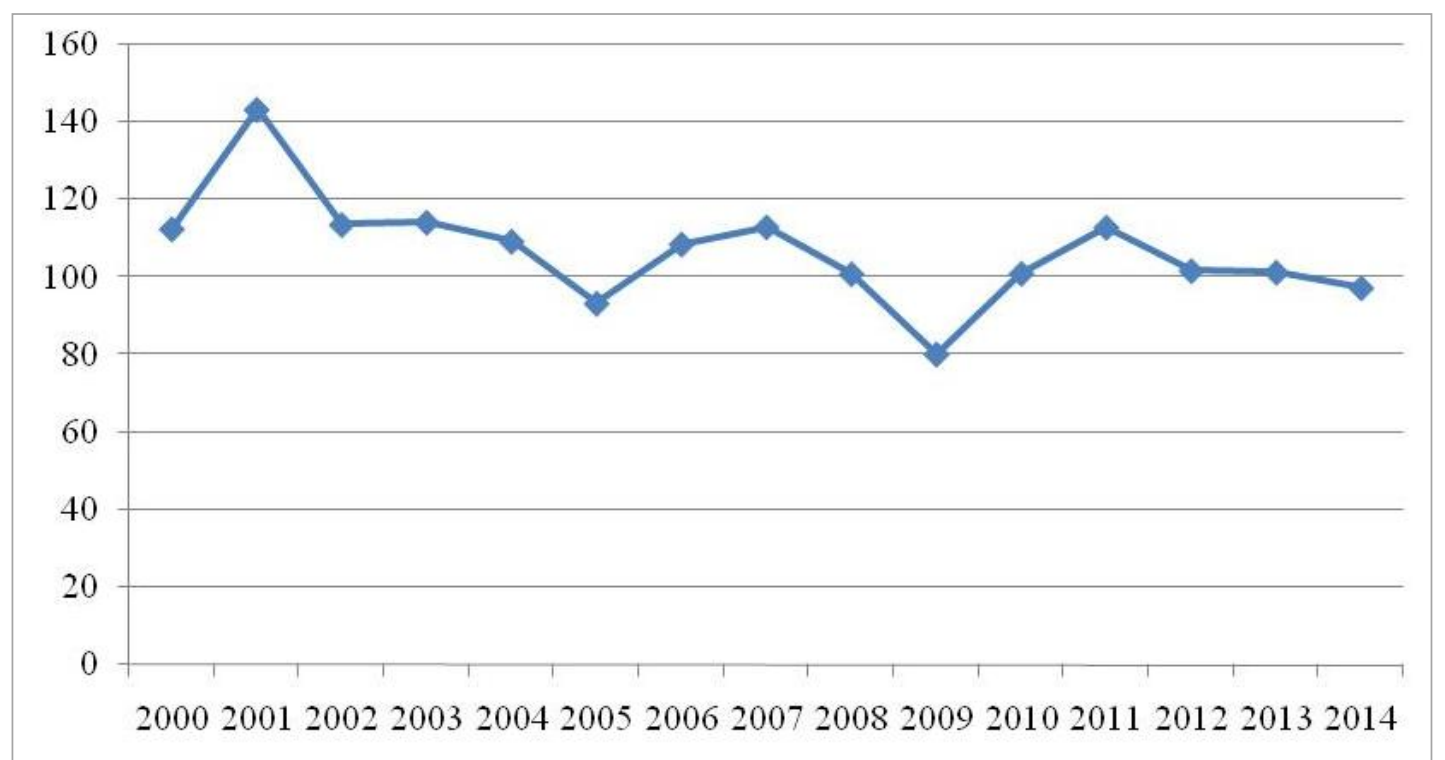

Fig. 2. Dynamics of indexes of industrial production in Lviv Region for the period of 2000-2014, expressed in percents. Calculated on the basis of the data from Main Department of Statistics of Lviv Region

In 2014 in comparison with 2013 index of industrial production is $96.9 \%$. Production volume in the enterprises of mining industry and development of quarries has increased by $2.0 \%$. In processing industry in 2014 in comparison with 2013 industrial output has fallen by $3.1 \%$. In enterprises of manufacture of wood products, paper production and printing activity industrial output concerning 2013 has fallen by $7.2 \%$. Production volume has also decreased in enterprises of steel production, production of fabricated metal products, in enterprises of engineering, in enterprises of chemical products and chemical substances production, in enterprises of food products, drinks and tobacco production and also in enterprises of supplying of electrical energy, gas, vapor and condensed air (MAIN DEPARTMENT OF STATISTICS, 2015).

While estimating the contribution of the region into Gross Domestic Product of Ukraine it should be noted, that in 2012 by this indicator Lviv Region took $7^{\text {th }}$ place. The region has $4.2 \%$ of GDP of Ukraine. GDP indicator per 1 person is $24387 \mathrm{UAH}$, which in general corresponds to average meaning in Ukraine.

While analyzing competitiveness index, which includes 12 indicators, in particular institutional demands, the level of infrastructure development, macroeconomic indicators, education and health protection branches condition, effectiveness of 
goods and labor market, level of financial market development, innovation activity, small and medium business and others (ZAKHAROVA, 2013), it should be mentioned, that Lviv Region is one of the leaders in Ukraine, in 2013 it took $6^{\text {th }}$ place, after the city of Kyiv, Kharkiv, Odessa, Donetsk and Dnipropetrovsk Regions.

\subsection{Science and education}

The regional center the city of Lviv is one of the biggest educational centers of Ukraine. By number of educational establishments and students Lviv goes right after our capital Kyiv and the city of Kharkiv. Potentially the educational institutions of Lviv can satisfy educational demands not only of the population of the region, but also inhabitants of neighboring border regions. The region is an important research center, in which $7.2 \%$ organizations of Ukraine are situated, they perform scientific and scientific-technical works, 3239 executives of research works are employed here. In connection with financial-economic problems of Ukraine during the last decades the financing of a science and research activity was catastrophically decreased, it negatively impacts the social sphere condition. Unfortunately it also negatively influences investment attractiveness of the region.

In 2014 in the region there were 72 organizations, which were performing scientific studies and developments. During the last years the number of enterprises, which implemented innovations, has increased. The similar tendency is observed while implementing new technological processes after economic crisis in 2009, the implementation of such processes increases (Fig. 3).

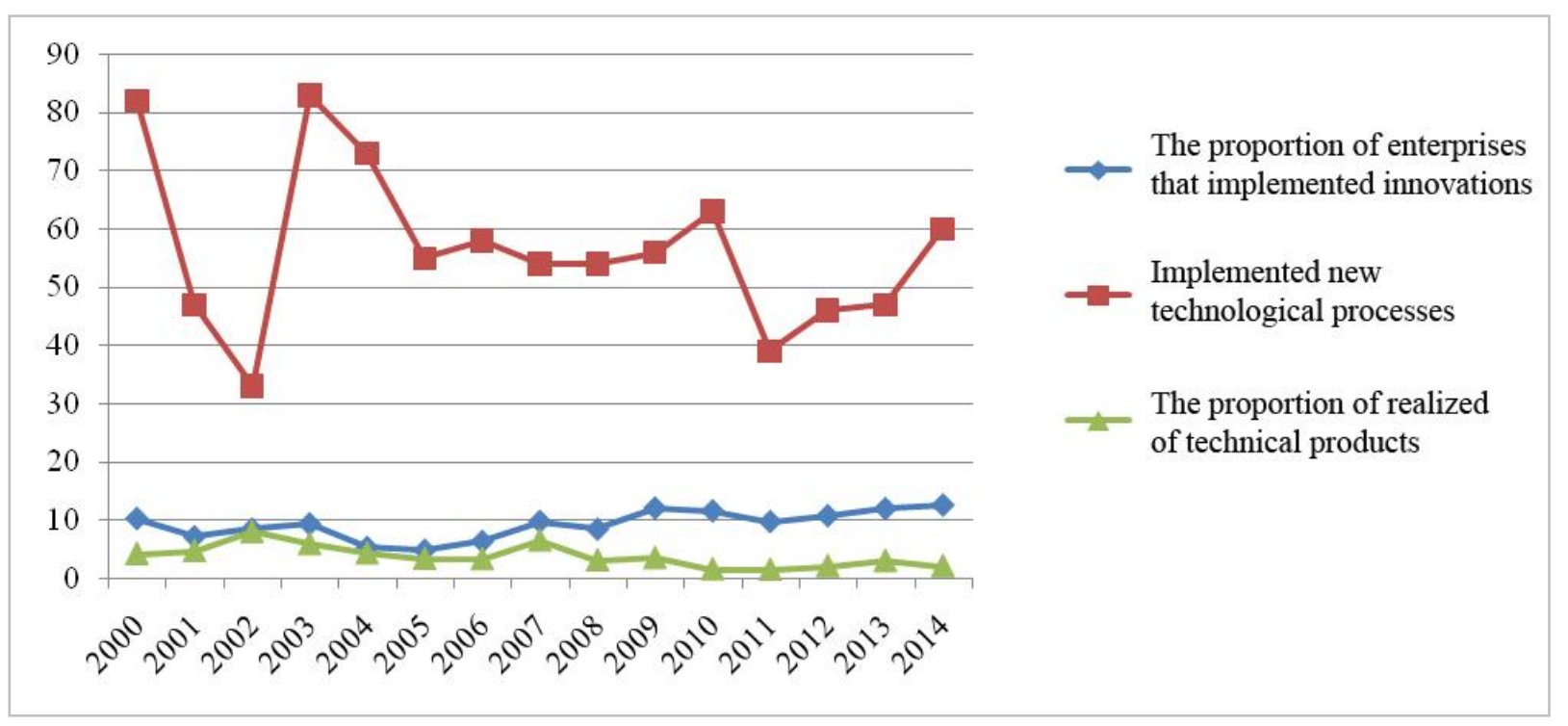

Fig. 3. Dynamics of innovations implementation in enterprises of Lviv Region for the period of 2000-2014. Processed on the basis of the data from Main Department of Statistics of Lviv Region

Capital investments during the last 3 years decrease. In contradiction to capital, direct foreign investments from year to year increase. The most of investments comes from the Republic of Poland.

\subsection{Business and labor market}

An important role in social-economic development of the region small and medium business plays. As it is known, small business is the most dynamical sector of economics, the quality of life of the population depends largely on the level of its development, as the main purpose of the business activity is providing of stable increasing of the number of middle class of a society.

Lviv Region as a border region of Ukraine has additional opportunities in the development of small business at the cost of usage of advantages of its economic-geographical position. Today the region is one of the leaders among the regions of Ukraine by indicators of small business development; it takes $5^{\text {th }}$ place by the number of small enterprises in Ukraine. The level of the registered unemployment at the end of 2014 was $1.6 \%$ of the population of the working age. Another indicator, which depicts the standard of living of the population, is the average amount of gross wages and the average amount of pensions. In 2012 the average monthly gross wages for the population of Lviv Region 
was only $2578 \mathrm{UAH}$. The population of the retirement age is in worse situation, as the average monthly pension is only $1,152 \mathrm{UAH}$.

\subsection{Prices. The criminal situation}

Consumer price index during the last 3 years increases. This index in December 2014 in comparison with November in Lviv Region was 103.6\% (in Ukraine - 103.0\%). In Lviv Region in December 2014 in comparison with November 2014 the prices of food and soft drinks increased by $4.3 \%$, which negatively impacts the level of life of the society. The most growth of prices is of vegetables - by $20.3 \%$.

Accordingly the information of Public Prosecutor's Office in Lviv Region in 2014 there were registered 21,6 thousands of criminal crimes (in comparison with 2013 it is more by $4.8 \%)$,

\section{Conclusions}

The performed study indicates, that Lviv Region, being one of the border regions of Ukraine, is characterized by high enough socialeconomic development, positive balance of migration movement of the population. In age structure the population of the working age prevails. At the same time the adverse demographic tendencies are observed in the region, in particular depopulation of the population is a result of the negative natural increase. Non-productive branch, the part of which is a scientific potential (research and project-design establishments, higher educational institutions), financial organizations, trade enterprises and food industry, which totally can satisfy the needs of the region, are relatively well developed. Under the circumstances of the border position the sector of small and medium business has a special meaning in the development of the region.

Lviv Region is characterized by significant part of high-qualified labor resources; that is why the preservation and development of working capacity, expanded reproduction of skilled labor and increasing of its competitiveness corresponding to the modern needs of economic and social development are becoming increasingly important. The change of the situation for better is possible only at the cost of the region and proper regional policy, aimed at improvement of the region's image, including at the cost of activation of innovation and educational activity.

Western Ukraine, especially Lviv Region, has important cultural places for many European cultures, in connection with situation and historic peculiarities of the region. Historic center of Lviv is listed in the UNESCO World Heritage List. Politic and trade role of Lviv always attracted some number of ethnic groups with different cultural and religious traditions, which were different but mutually connected communities of the city, the evidence of which always was and is the city architectural landscape. The cultural heritage of Lviv Region attracts a large number of foreign tourists. The road infrastructure is at the insufficient level, especially the condition of roads, touristic signs and sanitary items (TomcZEWSKA-PoPowYCZ, 2015). That is why there is a big need of improvement of touristic infrastructure, which can become a very important component in the improvement of the economic situation of the region. The attention must be paid to the development of sentimental (ethnic), active, castle and other kinds of tourism and arrangement of the touristic infrastructure for foreign tourists.

Having declared its Eurointegration course Ukraine must use new instruments of regional development, one of which is cross-border cooperation. Authorities of Lviv Region must work out the Strategy of the development, including the development of human capital, increasing of competitiveness. The direction of the development must be also aimed at forming of innovation economic environment and optimization of the area of the region, monitoring of geographic processes and working out of systems of monitoring of strategy realization.

\section{References:}

Analiz sanitarno-epidemiologichnoi situaciï u L'vivs'kij oblasti ta pokazniki dijal'nosti derzhsanepid sluzhbi za 20062010 roki. 2011. Golovne upravlinnja sanitarnoepidemiologichnoï sluzhbi u L'vivs'kij oblisti, L'viv.

Butko M. 2005. Regional'ni osoblivosti ekonomichnih transformacij v perehidnij ekonomici, disertacija na zdobuttja naukovogo stupenja doktora ekonomichnih nauk. Kï̈v.

Cherevko 0. 2007. Strategiya social'no-ekonomichnogorozvitku regioniv Ukraïni. Disertaciya na zdobuttya naukovogo stupenya doktora ekonomichnix nauk, Kiïv.

Dovkillja L'vivshhini: statistichnij zbirnik, 2013. Golovne upravlinnja statistiki u L'vivs'kij oblasti, L'viv.

Korotich O.B. 2006. Derzhavne upravlinnja regional'nim rozvitkom Ukraïni. HarRI NADU "Magistr".

Korotich O.B. 2007. Rozvitok Ukraïni v naprjamku dosjagnennja evropejs'kih standartiv zhittja. [in] Derzhavne budivnictvo, HarRI NADU.

Korotich O.B. 2008. Problemi rozvitku regioniv Ukraïni ta zavdannja derzhavnoi regional'noi politiki. [in] Teorija ta praktika derzhavnogo upravlinnja, HarRI NADU "Magistr", 3 (22): 208-215.

Main Department of Statistics in Lviv Region (Головне Управління статистики у Львівській області) - Golovne Upravlinnya statistiki u L'vivs'kij oblasti: http://lv.ukrstat.gov.ua/ 
Nemec L., Kuleshova A., Segida K., Kljuchko L. 2014. Social'no-jekonomicheskie aspekty razvitija prigranichnogo regiona v uslovijah sovremennyh processov evrointegracii (na primere har'kovskoj oblasti Ukrainy). Acta Geogr. Silesiana, 17: 41-47.

Official website of Main Department of Statistics (Державна служба статистики України) - Derzhavna sluzhba statistiki Ukraïni: http://www.ukrstat.gov.ua/

Pantylej W. 2008. Przemiany społeczno-gospodarcze a stan zdrowia ludności Ukrainy i Polski w latach 1990-2002. Wyd. UMCS, Lublin.

Riven' zhittya naselennya Ukraïni, 2006. Cheren'ko L. (ed.) Institut demografiï ta social'nix doslidzhen', NAN Ukraïni, Derzhavnij komitet statistiki Ukraïni, Konsul'tant, Kiïv.
Social'ni indikatori rivnya zhittya naselennya L'vivs'koï oblasti: statistichnij zbirnik, 2013. Golovne upravlinnya statistiki L'vivs'koï oblasti, L'viv.

Tomczewska-Popowycz N. 2015. Zamki i pałace Ukrainy atrakcją dla turystów z Polski. Turystyka kulturowa, $6 / 2015$.

Zaharova Yu. Perspektivy razvitiya regiona v 2013-2017 gg. http://www.ey.com/Publication/vwLUAssets/3_Перспект иви_розвитку_харківського_регіону_2013-2017_Рос.мова Zastavnij F. 1994. Geografija Ukraïni. Svit.

Zolkina M. 2014. Gromads'ka dumka shhodo Evrointegracii: novi trendi jak shans na konsolidaciju suspil'stva. [in] Evrointegracija Ukraïni. Dosvid susidiv ta perspektivi $o b^{\prime} \epsilon$ dnannja suspil'stva. Fond «Demokratichni iniciativi imeni Il'ka Kucheriva», Kiïv: 8-25. 